\title{
Unilateral condylar hyperplasia: evaluation of six cases
}

\author{
- Ana Carolina Uchoa Vasconcelos Ph.D Student, Postgraduated Program, Dental College, Federal University of Pelotas \\ - Brazil - Felipe Martins Silveira Graduate Student, Graduation Program, Dental College, Federal University of Pelotas \\ - Brazil • Adriana Etges Ph.D., Postgraduated Program, Dental College, Federal University of Pelotas - Brazil • Ana \\ Paula Neutzling Gomes Ph.D., Postgraduated Program, Dental College, Federal University of Pelotas - Brazil • João Luís \\ Carlini Oral and Maxillofacial Surgeon - Marcus Cristian Muniz Conde Ph.D., Postgraduated Program, Dental College, \\ Federal University of Pelotas - Brazil - Sandra Beatriz Chaves Tarquínio Ph.D., Postgraduated Program, Dental College, \\ Federal University of Pelotas - Brazil
}

ABSTRACT | This study aimed to report six cases of unilateral condylar hyperplasia (CH), regarding their demographic and clinical characteristics and imaging and histopathological findings. Sex, age, affected side, history of the case, complementary examinations and treatment were recorded. Five cases (83.3\%) were of females and the mean age of the study population was of 19.3 years (range: 14 -28 years). The right condyle was affected in four cases (66.6\%). Five (83.3\%) patients were subjected to condylotomy, and high condylectomy was done in one (16.6\%) case. The patients were followed postoperatively for a mean period of 27.5 months. All patients received surgical and orthodontic treatment. In the present study, $\mathrm{CH}$ occurred more frequently in the first decades of life and was more prevalent in females. The right condyle was more affected than the left one and high condylotomy combined with orthodontics was the main treatment performed. Dental surgeons should be aware that facial asymmetry is the chief complaint of few patients, who may also present temporomandibular diseases.

DESCRIPTORS | Hyperplasia; Facial Asymmetry; Mandibular Condyle.

RESUMO | Hiperplasia condilar: avaliação de seis casos • O presente estudo tem por objetivo avaliar seis casos de hiperplasia condilar (HC), relacionando suas características clínico-demográficas e seus achados imaginológicos e histopatólogicos. Dados de sexo, idade, lado afetado, histórico do caso, exames complementares e tratamento foram coletados. Cinco casos (83.3\%) acometeram indivíduos do sexo feminino e a idade média da população avaliada foi de 19,3 anos (faixa: 14-28 anos). O lado direito foi afetado em quatro casos (66.6\%). Cinco (83.3\%) pacientes foram submetidos à condilotomia e um (16.6\%) à condilectomia. Os pacientes foram acompanhandos por um período pós-operatório médio de 27,5 meses. Todos os pacientes receberam tratamentos cirúrgico e ortodôntico. Neste relato, a HC ocorreu mais frequentemente nas primeiras décadas de vida e foi mais prevalente em indivíduos do sexo feminino. O côndilo direito foi mais afetado que o esquerdo e a condilotomia combinada com o tratamento ortodôntico foi a principal conduta realizada. O cirurgiãodentista deve reconhecer que somente alguns pacientes apresentam queixa primária de assimetria facial, e que estes podem apresentar, também, desordens temporomandibulares.

DESCRITORES | Hiperplasia; Assimetria Facial; Côndilo Mandibular.

CORRESPONDING AUTHOR: | • Ana Carolina Uchoa Vasconcelos Serviço De Patologia Bucal, Universidade Federal De Pelotas - Ufpel • Rua Gonçalves Chaves, 457, Sala 608 Pelotas, Rs, Brazi • 96015-560 E-mail: carolinauv@gmail.com

- Received May 04, 2015 - Accepted May 27, 2015

- Dol http://dx.doi.org/10.11606/issn.2357-8041.clrd.2015.90855 


\section{INTRODUCTION}

Condylar hyperplasia $(\mathrm{CH})$ is a disorder characterized by overdevelopment of the mandibular condyle, which may manifest unilaterally or bilaterally, causing facial asymmetry, mandibular deviation, malocclusion and articular dysfunction. ${ }^{1}$ Although the etiology of this condition remains unknown, factors such as trauma, arthritis, hormonal disturbances, infection and heredity have been implicated. ${ }^{2,3}$ Females make up a larger proportion of affected individuals, and growth disturbance is generally seen in patients between the ages of 10 and 30 years, with a reported mean age of approximately 23.3 years. ${ }^{4,5}$

The diagnosis of $\mathrm{CH}$ may be made by a combination of clinical, radiological and histopathological findings. Radiological examination and bone scintigraphy are the most important imaging tools to evaluate this type of disorder. ${ }^{6}$ While the former may show abnormalities in the size and morphology of the condylar head and/or neck regions, the latter is an essential diagnostic method for visualizing hyperactivity in the condyle.7 Beyond these tests, 3-dimensional stereophotogrammetry has recently proved to be a new important tool that provides a more in-depth evaluation of the asymmetry of the mandible. ${ }^{8}$ These additional examinations are important instruments for early diagnosis and can help in the differentiation of $\mathrm{CH}$ and other pathologies such as hemifacial hypertrophy, unilateral macrognathia, laterognathia, osteoma, chondroma, osteochondroma and chondrosarcoma. ${ }^{1,9}$ Four histologically different types of mandibular $\mathrm{CH}$ can be found, depending on the arrangement and morphology of the various layers of the condyle (fibrous articular layer, undifferentiated mesenchymal layer, transitional layer, and hypertrophic cartilage layer). ${ }^{10}$

Treatment generally consists of a combination of surgery and orthodontics and it is defined on the basis of age, degree of severity of the disease and the status of condylar growth..$^{5,11}$ Different surgical options have been proposed to treat this condition, ranging from high condylectomy to orthognathic surgery or even a combination of both. The aim of this work was to describe six cases of unilateral $\mathrm{CH}$, regarding their demographic and clinical characteristics as well as their imaging and histopathological findings, and also to evaluate the aesthetics and functional results after treatment.

\section{MATERIALS AND METHODS}

Six patients from a private practice were referred to a school of dentistry, with a chief complaint of facial asymmetry. Informed consent forms were signed by all patients or their parents or guardians, in the case of children. Sex, age, affected side, history of the case, complementary examinations and treatment were recorded. The criteria used for $\mathrm{CH}$ diagnosis was based on clinical aspects, imaging assessments and histopathological characteristics. Occlusion and crossbite were evaluated to determine deviation of midline. Imaging assessment of the joints was carried out with panoramic radiography and scintigraphy. Scintigaphy using 99mTcMDP has been advocated as a method of diagnosis and pre-surgical assessment of patients with condylar hyperplasia, aiming to distinguish the growing from non-growing condyle. All patients were operated under general anesthesia with nasoendotracheal intubation. The patients were subjected to high condylotomy (surgical procedure to remove the upper portion of the condyle) or condylectomy (surgical procedure to remove the entire condyle). Sagittal split osteotomy was planned and performed bilaterally, when gross asymmetry existed along with protrusion, and unilaterally, in cases of minor discrepancies. All the surgical specimens were stored in 10\% buffered formalin for histopathological analysis. All patients were evaluated postoperatively for their improvement in facial aesthetics, occlusion and any obvious complication. The 
data were analyzed by descriptive statistics, using the SPSS 17.0 software (Statistical Package for the Social Sciences, Chicago, IL, USA).

\section{RESULTS}

The present study was conducted in six patients, all of them with clinical diagnosis of $\mathrm{CH}$. Five cases were females (83.3\%) and the mean age of the study population was 19.3 years (range: 1428 years). The right condyle (four cases $-66.6 \%$ ) was more affected than the left (two cases $33.3 \%)$. None showed a history of trauma. Facial asymmetry with midline shift to the left side was seen in four cases (66.6\%). In each patient, the scintigraphy showed areas of abnormal increased uptake on the affected condyles. Histopathological examination revealed hypertrophic cartilage layer, fibrous articular layer, undifferentiated mesenchymal layer and cartilage islands in the deep layers of the trabecular bone. The hypertrophic cartilage layer was organized in islands invading the trabecular bone. A fibrous articular layer was seen above it, followed by an undifferentiated mesenchymal layer. Five (83.3 \%) patients were subjected to high condylotomy and one (16.6\%) was treated with condylectomy. One (16.6\%) needed to undergo a second surgical intervention to correct residual facial asymmetry. All patients were subjected to orthodontic treatment at some stage of the disease. The patients were followed regularly in their postoperative phase for a mean period of 27.5 months (Figure 1/Table 1).
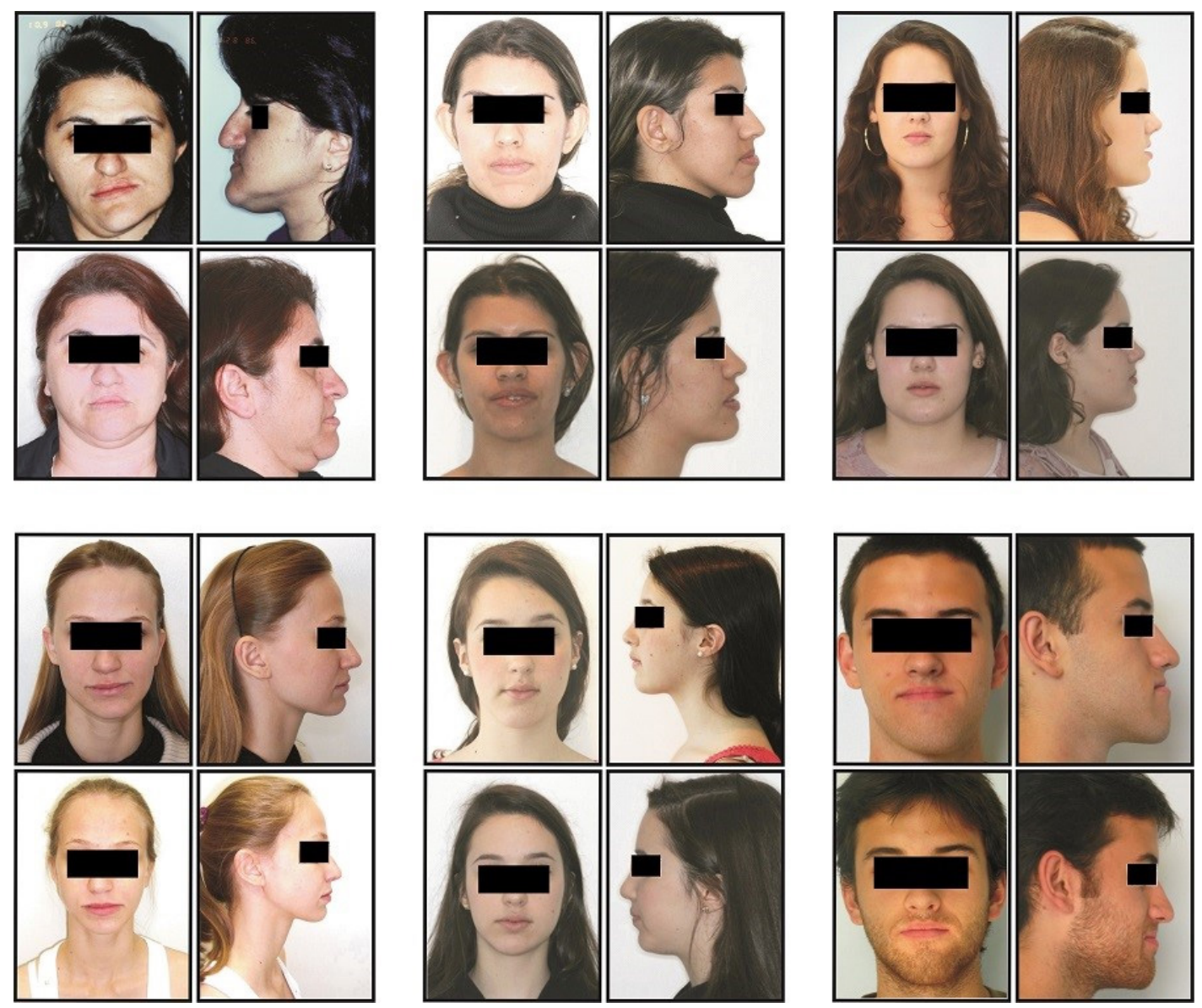

Figure 1 | Preoperative and postoperative pictures of all cases. 
Table 1 | Demographic data, clinical features and treatment

\begin{tabular}{|c|c|c|c|c|c|c|c|c|c|}
\hline Patient & Age & Sex & $\begin{array}{l}\text { Condyle } \\
\text { affected }\end{array}$ & $\begin{array}{l}\text { Asymmetry/ } \\
\text { Side }\end{array}$ & Trauma & $\begin{array}{l}\text { Panoramic/ } \\
\text { Scintigraphy }\end{array}$ & Surgical treatment & $\begin{array}{l}\text { Second } \\
\text { surgery }\end{array}$ & Follow-up \\
\hline 1 & 28 & $\mathrm{~F}$ & Right & Yes/Left & No & Yes & $\begin{array}{l}\text { Osteotomy + High } \\
\text { Condylectomy }\end{array}$ & Yes & 8 years \\
\hline 2 & 21 & $\mathrm{~F}$ & Right & Yes/Left & No & Yes & Condylotomy & No & 4 months \\
\hline 3 & 16 & $\mathrm{~F}$ & Left & Yes/Right & No & Yes & Condylotomy & No & 4 months \\
\hline 4 & 18 & $\mathrm{~F}$ & Right & Yes/Left & No & Yes & Osteotomy + Condylotomy & No & 3 months \\
\hline 5 & 14 & $\mathrm{~F}$ & Left & Yes/Right & No & Yes & Condylotomy & No & 10 months \\
\hline 6 & 19 & M & Right & Yes/Left & No & Yes & Osteotomy + Condylotomy & No & 4 years \\
\hline
\end{tabular}

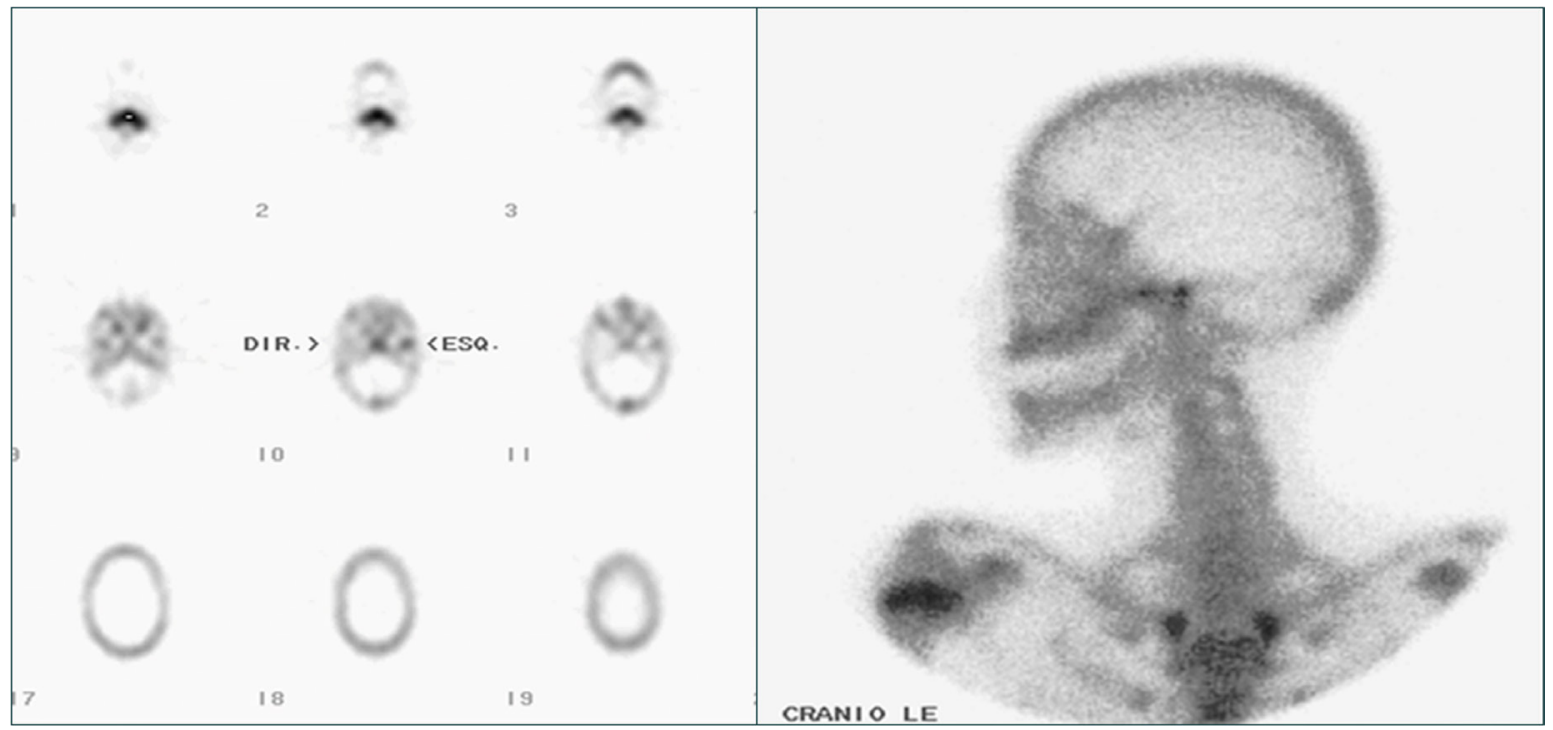

Figure 2 | Bone scintigraphy: increased uptake in the left condyle.

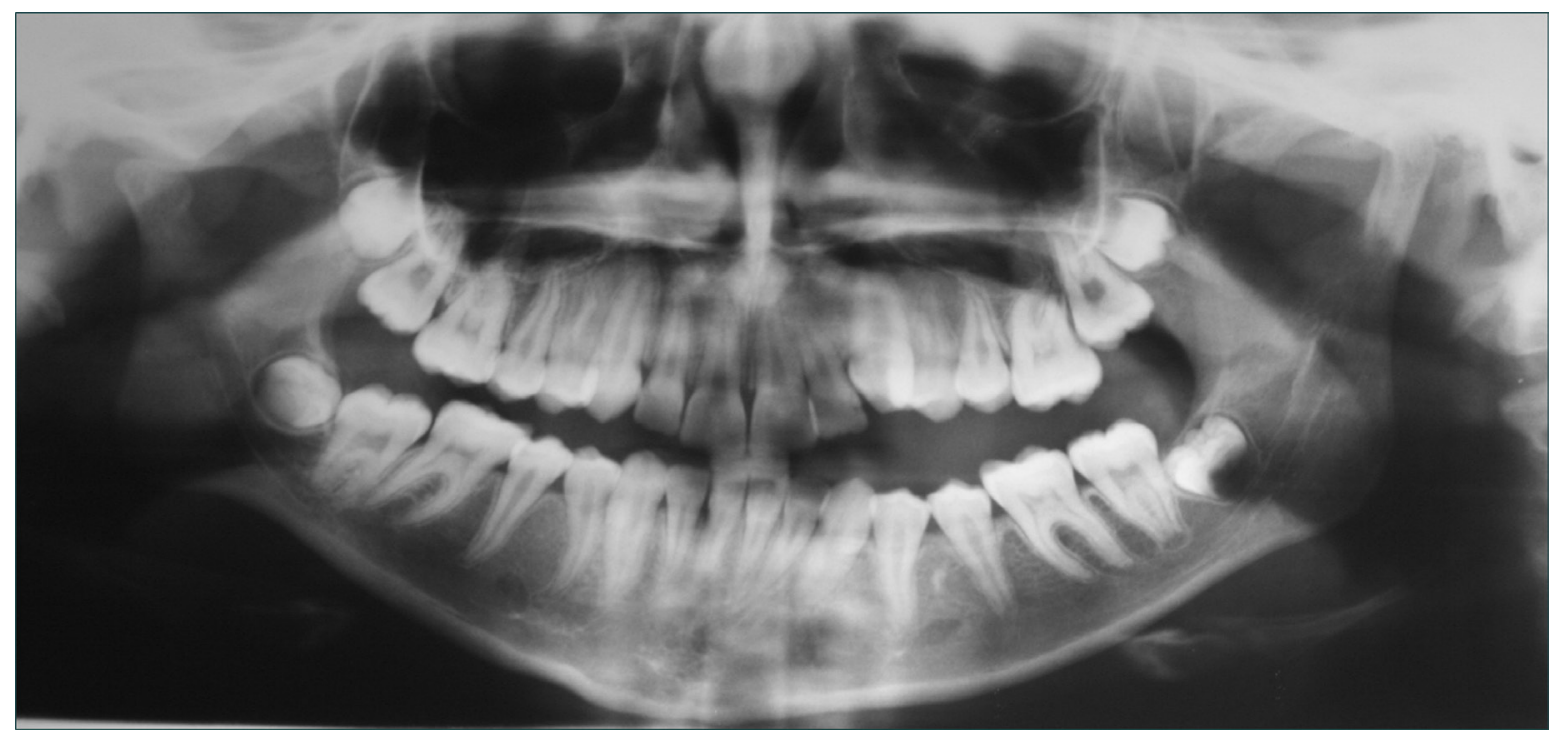

Figure 3 | Panoramic view - the left condyle is slim and long. 

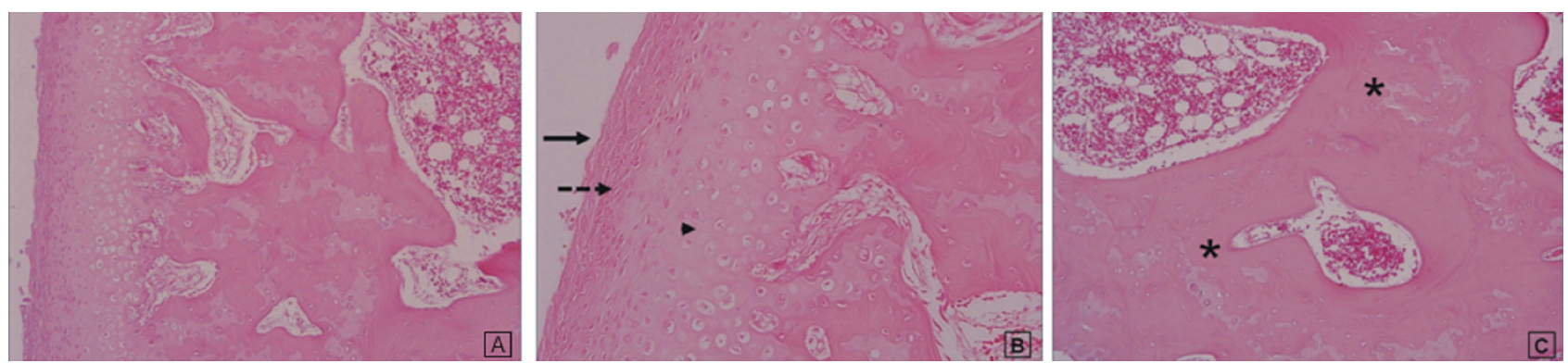

Figure 4 || A: Hypertrophic cartilage layer (H\&E, X40); B: Fibrous articular layer $(\longrightarrow$ ) undifferentiated mesenchymal layer ( - - $\rightarrow$ ) and hypertrophic cartilage layer $(\rightarrow)(H \& E, X 200)$; C: Cartilage islands in the deep layers of trabecular bone (*) (H\&E, X200).

Table 2 | Histological classification of mandibular condylar hyperplasia described by Slootweg and Müller

\begin{tabular}{c|l} 
Histological classification & \multicolumn{1}{c}{ Characteristics } \\
\multicolumn{1}{c|}{ Type I } & $\begin{array}{l}\text { Broad proliferation zone } \\
\text { Underlying thick layer of hyaline cartilage growth } \\
\text { Bone containing numerous cartilage islands }\end{array}$ \\
\hline Type II & $\begin{array}{l}\text { Patchy distribution (cell-rich areas alternating with nonproliferative, cell-poor zones) } \\
\text { Cartilage islands in cancellous bone are less frequent than in type I }\end{array}$ \\
\hline Type III & $\begin{array}{l}\text { Great distortion } \\
\text { Irregularly shaped masses of hyaline cartilage extending into cancellous bone of condylar neck } \\
\text { or encroaching upward into superficial articular layer }\end{array}$ \\
\hline Type IV & $\begin{array}{l}\text { Continuous subchondral bone plate covered by cell-poor fibrocartilaginous layer } \\
\text { No proliferation layer of hyaline cartilage growth } \\
\text { Burned-out appearance of condyle }\end{array}$ \\
\hline
\end{tabular}

\section{DISCUSSION}

$\mathrm{CH}$ is a disorder of unknown etiology characterized by persistent or accelerated growth, usually creating not only an aesthetic problem but also a functional abnormality.9,12 Slowly progressive unilateral enlargement of the head and neck of the condyle causes crossbite malocclusion, facial asymmetry, and shifting of the midpoint of the chin to the unaffected side. The facial appearance of patients with this disturbance depends on the age and the time course of the disease. ${ }^{13}$

In the present study, most of the cases were females (83.3\%). Such result is in agreement with previous reports. Nitzan et al. ${ }^{14}$ investigated 61 patients, of which 46 (75\%) were females. VillanuevaAlcojol et al.15, studying 36 patients, found that 25 (69\%) were women. Even though some authors have observed a similar incidence in males and females ${ }^{5,16,17}$, others have found women to be slightly overrepresented. ${ }^{14,15,18}$ The identification of sex hormone receptors around the temporomandibular joint (TMJ) and the psychosocial factor that strongly motivates women to seek professional help in cases of facial asymmetry may explain our findings. ${ }^{4,19}$

After evaluating cases diagnosed with $\mathrm{CH}$, Gray et $a{ }^{17}$ and Saridin et al. ${ }^{20}$ observed that the mean age was respectively 25.8 and 21.5 years. In the present study, the mean age was 19.3 years. This age is below the mean observed in previous studies. However, Matteson et al. ${ }^{5}$ demonstrated that the ages of patients with this condition may vary between 10 and 30 years, covering the average age found in this research. The pubertal onset of condylar hyperplasia strongly suggests hormonal 
influence in its etiology.4,19 Although other studies $^{1,14}$ reported that trauma is an important factor on the etiopathogeny of $\mathrm{CH}$, no case in the present study revealed a history of trauma. The literature hypothesizes that infection, heredity, intrauterine disturbances and hypervascularity can be considered predisposing factors. ${ }^{1,19}$

Regarding laterality of $\mathrm{CH}$, the results of this study showed a slight connection between females and right condyle: three of five females (60\%) showed involvement of the right condyle. Although some authors ${ }^{4,15}$ were not able to demonstrate significant differences when comparing affected condyle and gender, Nitzan et al. ${ }^{14}$ showed the relationship between affected right side in females and left side in males. Further studies with a large number of cases are needed to confirm these data.

The diagnosis of $\mathrm{CH}$ should be made by a combination of clinical, imaging and histological findings. ${ }^{10}$ Scintigraphy showed hyperactivity of one of the condyles, which was consistent with clinical findings (Figure 2). It is important to emphasize that this examination should be evaluated in light of clinical findings. It is also necessary to bear in mind that this bone scanning technique, although highly sensitive, is nonspecific and that it does not necessarily correlate with active growth, because the results can indicate inflammatory conditions, infection, healing after traumatic injuries or evidence of neoplastic lesions. ${ }^{15}$ Laverick et al. ${ }^{7}$ considered plain radiographs an important method to show enlarged or elongated condyle, determining possible differences in size, shape and length of its structure, but giving no information about condylar growth cessation (Figure 3).

In describing the histological characteristics of specimens showing hyperplastic condyles, similarly to other authors ${ }^{2,15,17}$, we observed the presence of a hypertrophic cartilage layer, which was organized in islands invading the trabecular bone. A fibrous articular layer was seen above it, followed by an undifferentiated mesenchymal layer (Figure 4). These histological features corresponded to $\mathrm{CH}$ type I, as described by Slootweg and Müller ${ }^{21}$ (Table 2).

Considering the treatment, five patients (83.3\%) underwent high condylotomy and all of them were subjected to orthodontic treatment. According to some authors, a combination of orthodontic-maxillofacial treatment and surgery may produce good aesthetic and functional results. ${ }^{12,22}$ The specific growth pattern of the condyle can influence the timing of the surgery and the type of surgical procedures. ${ }^{13}$ Removal of the condyle is indicated for patients with abnormally high growth activity and it should be performed as early as possible to avoid further facial asymmetry - with maxillary and soft tissue damage. ${ }^{3,23,24}$ Due to the satisfactory aesthetic and functional results of the surgeries, the surgeons did not detect the necessity for osteotomy of the maxilla.

One of the patients in this study underwent a second surgical intervention to correct residual facial asymmetry. Jones et al. ${ }^{11}$ reported that 2-stage surgery is sometimes necessary to correct asymmetry, but emphasized that refusing a second surgical procedures is common among the patients. In the present study, the cases were followed regularly in the postoperative phase for a mean period of 27.5 months - similar to the postoperative follow-up of 2 years in a study by Mehrota et al. ${ }^{1}$, of five patients diagnosed with $\mathrm{CH}$. Few reports are available regarding the long-term follow-up of patients after condyIectomy or high condylotomy.

In this study, $\mathrm{CH}$ occurred more frequently in the first decade of life and was more prevalent in females. The right condyle was more affected than the left one and high condylotomy combined with orthodontics was the principal treatment of choice. Dental surgeons should be aware that facial asymmetry is the chief complaint of few patients, who 
may also present temporomandibular diseases. Surgical treatment combined with orthodontics achieved optimal aesthetic and functional results.

\section{ACKNOWLEDGEMENTS}

We thank A. Leyva, PhD, (USA) for editing the manuscript in English.

\section{CONFLICT OF INTEREST STATEMENT}

We declare no conflict of interest.

\section{REFERENCES}

1. Mehrotra D, Dhasmana S, Kamboj M, Gambhir G. Condylar hyperplasia and facial asymmetry: report of five cases. J Maxillofac Oral Surg. 2011 Mar;10(1):50-6. doi: 10.1007/ S12663-010-0141-5.

2. Eslami B, Behnia H, Javadi H, Khiabani KS, Saffar AS. Histopathologic comparison of normal and hyperplastic condyles. Oral Surg Oral Med Oral Pathol Oral Radiol Endod. 2003 Dec;96(6):711-7. doi: 10.1016/S1079-2104(03)00379-2.

3. Sugawara Y, Hirabayashi S, Susami T, Hiyama S. The treatment of hemimandibular hyperplasia preserving enlarged condylar head. Cleft Palate Craniofac J. 2002 Nov;39(6):64654. doi: 10.1016/So278-2391(96)90342-o.

4. Raijmakers PG, Karssemakers LH, Tuinzing DB. Female predominance and effect of gender on unilateral condylar hyperplasia: a review and meta-analysis. J Oral Maxillofac Surg. 2012 Jan;70(1):e72-6. doi: http://dx.doi.org/10.1016/j. joms.2011.05.026.

5. Matteson SR, Proffit WR, Terry BC, Staab EV, Burkes EJ Jr. Bone scanning with 99mtechnetium phosphate to assess condylar hyperplasia. Report of two cases. Oral Surg Oral Med Oral Pathol. 1985 Oct;6o(4):356-67. doi: http://dx.doi. org/10.1016/0030-4220(85)90255-5.

6. Shintaku WH, Venturin JS, Langlais RP, Clark GT. Imaging modalities to access bony tumors and hyperplasic reactions of the temporomandibular joint. J Oral Maxillofac Surg. 2010 Aug;68(8):1911-2. doi: 10.1016/j.joms.2009.09.023.

7. Laverick S, Bounds G, Wong WL. [18F]-fluoride positron emission tomography for imaging condylar hyperplasia. $\mathrm{Br}$ J Oral Maxillofac Surg. 2009 Apr;47(3):196-9. doi: 10.1016/j. bjoms.2008.08.001.

8. Verhoeven TJ, Nolte JW, Maal TJ, Bergé SJ, Becking AG. Unilateral condylar hyperplasia: a 3-dimensional quantifi- cation of asymmetry. PLoS One. 2013 Mar;8(3):e59391. doi: 10.1371/journal.pone.0059391.

9. Yang J, Lignelli JL, Ruprecht A. Mirror image condylar hyperplasia in two siblings. Oral Surg Oral Med Oral Pathol Oral Radiol Endod. 2004 Feb;97(2):281-5. doi: 10.1016/j. tripleo.2003.08.027.

10. Fariña RA, Becar M, Plaza C, Espinoza I, Franco ME. Correlation between single photon emission computed tomography, AgNOR count, and histomorphologic features in patients with active mandibular condylar hyperplasia. J Oral Maxillofac Surg. 2011 Feb;69(2):356-61. doi: 10.1016/j.joms.2010.06.184.

11. Jones RH, Tier GA. Correction of facial asymmetry as a result of unilateral condylar hyperplasia. J Oral Maxillofac Surg. 2012 Jun;70(6):1413-25. doi: 10.1016/j.joms.2011.03.047.

12. Cervelli V, Bottini DJ, Arpino A, Trimarco A, Cervelli G, Mugnaini F. Hypercondylia: problems in diagnosis and therapeutic indications. J Craniofac Surg. 2008 Mar;19(2):406-10. doi: 10.1097/SCS.obo13e318069019f.

13. Wolford LM, Morales-Ryan CA, García-Morales P, Perez D. Surgical management of mandibular condylar hyperplasia type 1. Proc (Bayl Univ Med Cent). 2009 Oct;22(4):321-9.

14. Nitzan DW, Katsnelson A, Bermanis I, Brin I, Casap N. The clinical characteristics of condylar hyperplasia: experience with 61 patients. J Oral Maxillofac Surg. 2008 Feb;66(2):3128. doi: 10.1016/j.joms.2007.08.046.

15. Villanueva-Alcojol L, Monje F, González-García R. Hyperplasia of the mandibular condyle: clinical, histopathologic, and treatment considerations in a series of 36 patients. $J$ Oral Maxillofac Surg. 2011 Feb;69(2):447-55. doi: 10.1016/j. joms.2010.04.025.

16. Chepla KJ, Cachecho C, Hans MG, Gosain AK. Use of intraoral miniplates to control postoperative occlusion after high condylectomy for the treatment of condylar hyperplasia. J Craniofac Surg. 2012 Mar;23(2):406-9. doi: 10.1097/ SCS.obo13e31824offo3.

17. Gray RJ, Sloan P, Quayle AA, Carter DH. Histopathological and scintigraphic features of condylar hyperplasia. Int J Oral Maxillofac Surg. 1990 Apr;19(2):65-71. doi:10.1016/ So901-5027(05)80196-1.

18. Muñoz MF, Monje F, Goizueta C, Rodríguez-Campo F. Active condylar hyperplasia treated by high condylectomy: report of case. J Oral Maxillofac Surg. 1999 Dec;57(12):1455-9. doi: 10.1016/So278-2391(99)90732-2.

19. GC R, Muralidoss H, Ramaiah S. Conservative management of unilateral condylar hyperplasia. Oral Maxillofac Surg. 2012 Jun;16(2):201-5. doi: 10.1007/s10006-011-0310-9. 
20. Saridin CP, Raijmakers P, Becking AG. Quantitative analysis of planar bone scintigraphy in patients with unilateral condylar hyperplasia. Oral Surg Oral Med Oral Pathol Oral Radiol Endod. 2007 Aug;104(2):259-63. doi: 10.1016/j.tripleo.2006.08.018.

21. Slootweg PJ, Müller H. Condylar hyperplasia. A clinicopathological analysis of 22 cases. J Maxillofac Surg. 1986 Aug;14(4):209-14. doi: 10.1016/So301-0503(86)80291-0.

22. Lippold C, Kruse-Losler B, Danesh G, Joos U, Meyer U. Treatment of hemimandibular hyperplasia: the biological basis of condylectomy. Br J Oral Maxillofac Surg. 2007 Jul;45(5):3536o. doi: 10.1016/j.bjoms.2006.10.011

23. Ferreira S, da Silva Fabris AL, Ferreira GR, Faverani LP, Francisconi GB, Souza FA, et al. Unilateral condylar hyperplasia: a treatment strategy. J Craniofac Surg. 2014 May;23(3):e256-8. doi: 10.1097/SCS.0000000000000554.

24. Wolford LM, Movahed R, Perez DE. A classification system for conditions causing condylar hyperplasia. J Oral Maxillofac Surg. 2014 Mar;72(3):567-95. doi: 10.1016/j. joms.2013.09.002. 